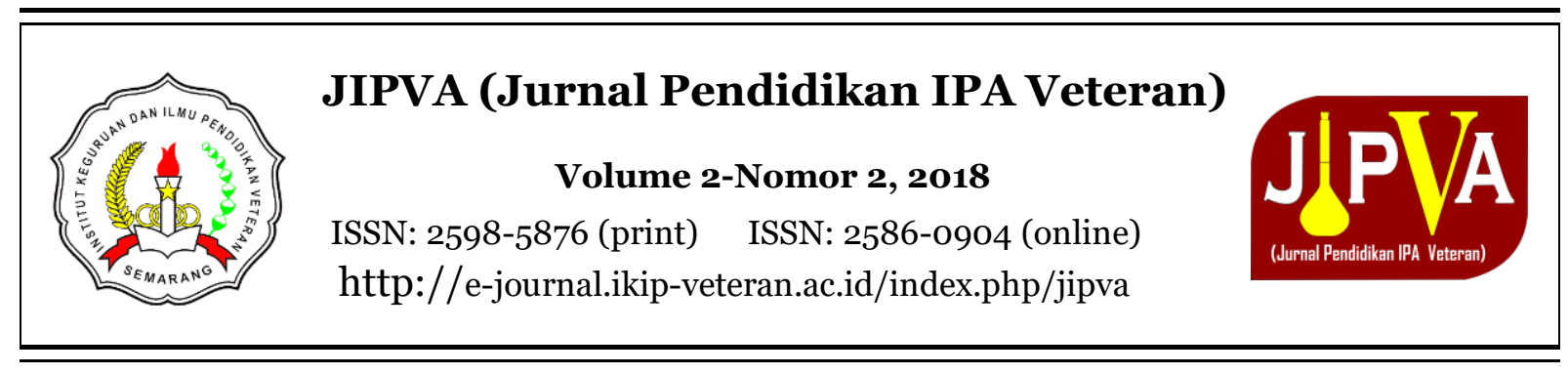

\title{
Project Based Learning untuk Meningkatkan Hasil Belajar Kimia Siswa Pokok Bahasan Hakikat Ilmu Kimia
}

\author{
Sasmono Sasmono \\ SMA Islam Sultan Agung 2 Kalinyamatan, Jepara, Indonesia \\ Author email: sasmono65@yahoo.co.id
}

Received: 19 November 2018; Revised: 23 November ; Accepted: 26 November 2018

\begin{abstract}
Abstrak
Tujuan dari penelitian ini adalah untuk mengetahui apakah pembelajaran menggunakan model Project Based Learning (PjBL) dapat meningkatkan hasil belajar siswa pada pelajaran kimia dengan pokok bahasan Hakikat Ilmu Kimia, serta untuk mengetahui besar peningkatannya. Metode penelitian ini adalah Penelitian Tindakan Kelas (PTK) yang dilaksanakan dalam 2 siklus. Variabel yang digunakan adalah peningkatan hasil belajar mencakup nilai kognitif dan psikomotorik. Adapun instrumen yang digunakan adalah pretes-postes, portofolio, lembar observasi, dan angket kuisioner. Data dianalisis secara deskriptif kualitatif. Dari hasil penelitian diperoleh gambaran siswa yang mencapai Kriteria Ketuntasan Minimal (KKM) nilai kognitif sebesar 97\% dengan rata-rata nilai 82, siswa yang mencapai KKM nilai psikomotorik sebanyak $100 \%$ dengan rata-rata nilai 91 . Terjadi peningkatan keberhasilan guru dalam menerapkan model pembelajaran PjBL pada siklus I sebesar 88\% meningkat pada siklus II sebesar $97 \%$. Peningkatan keaktifan rata-rata siswa pada siklus I sebesar $82 \%$, meningkat pada siklus II sebesar 93\%. Ketertarikan rata-rata siswa juga mengalami peningkatan pada siklus I sebesar $84 \%$ meningkat pada siklus II sebesar 92\%. Hasil observasi penerapan PjBL secara keseluruhan menunjukkan nilai sangat baik yaitu 95. Berdasarkan hasil analisis data tersebut menunjukkan bahwa pembelajaran menggunakan model Project Based Learning dapat meningkatkan hasil belajar siswa pokok materi hakikat ilmu kimia.
\end{abstract}

Kata Kunci: Hakikat Ilmu Kimia, Peningkatan Hasil Belajar; Project Based Learning.

\section{Project Based Learning to Improve Student Learning Outcome in Chemistry Lessons with the Subject Matter of the Nature of Chemistry Abstract}

The purpose of this study was to determine whether learning using the Project Based Learning model can improve student learning outcomes in chemistry lessons with the subject matter of the nature of Chemistry, and to determine the magnitude of the increase. Classroom Action Research is carried out in 2 cycles. The variables used are improvement in learning outcomes including cognitive, and psychomotor values. The instruments used were pretest-posttest, portfolio, observation sheet, and questionnaire questionnaire. Data were analyzed qualitatively descriptive. From the results of the study obtained a picture of students who reached KKM cognitive value as much as $97 \%$ with an average value of 82, students who achieved KKM psychomotor value as much as $100 \%$ with an average value of 91 . There was an increase in the success of teachers in applying the PjBL learning model in the first cycle of $88 \%$, increasing in the second cycle by $97 \%$. The increase in the average activity of students in the first cycle was $82 \%$, increasing in the second cycle by $93 \%$. The average interest of students also increases in the first cycle by 84\%, increasing in the second cycle by $92 \%$. Observation of the application of PjBL as a whole shows a very good value of 95. Based on the results of the analysis of the data shows that learning using the Project Based Learning model can improve student learning outcomes of the subject matter of the nature of chemistry. 
Keywords: The Nature of Chemistry; Improving Learning Outcomes;Based Learning.

How to Cite: Sasmono, S. (2018). Project Based Learning untuk Meningkatkan Hasil Belajar Kimia Siswa Pokok Bahasan Hakikat Ilmu Kimia. JIPVA (Jurnal Pendidikan IPA Veteran), 2(2), 189-200. doi:10.31331/jipva.v2i2.727

\section{PENDAHULUAN}

Berdasarkan konstruktivisme, diajarkan kepada siswa akan sulit dipahami tanpa penyampaian yang bermakna. Materi awal kimia pada kelas X semester gasal adalah Hakikat Ilmu Kimia sebagai jembatan awal perkenalan siswa terhadap ilmu Kimia. Dalam tahap awal persinggungan kimia yang belum didapatkan sewaktu sekolah sederajat SMP, penyajian pembelajaran kimia dituntut menarik dan dapat memotivasi siswa untuk menyukai kimia.

Komalasari (2009) mengungkapkan bahwa model pembelajaran kontekstual efektif karena diasumsikan bahwa proses pembelajaran akan benar-benar terjadi jika siswa dapat menemukan hubungan yang bermakna antara berpikir abstrak dengan aplikasi nyata dalam kehidupan. Pembelajaran berpendekatan kontekstual yaitu dengan memanfaatkan pengalaman awal siswa dalam pembelajaran dapat membantu siswa dalam mengkostruksi materi pelajaran, demikian juga belajar dengan melakukan dapat meningkatkan partisipasi siswa terlibat aktif dalam pembelajaran. Dengan siswa tertarik dan menyukai kimia diharapkan penyerapan materi kimia akan semakin mudah dan paradigma keliru tentang kimia sebagai momok pelajaran yang selalu dihindari akan sirna terhapuskan seiring berjalannya waktu. Tentu saja harapannya siswa akan bahagia dan bangga mempelajari Ilmu Kimia yang kedudukannya sebagai sentral berbagai Ilmu Pengetahuan Alam lainnya.
Berangkat dari latar belakang tersebut, perlu ditemukan cara terbaik untuk menyampaikan konsep yang diajarkan di dalam mata pelajaran pokok bahasan Hakikat Ilmu Kimia, sehingga siswa dapat mengkontruksi konsep-konsep tersebut sebagai suatu pijakan dasar kompetensi yang berguna untuk menunjang materi berikutnya. Di samping itu, guru dituntut kemampuannya untuk berkomunikasi secara efektif dengan siswa dengan memperkenalkan metode ilmiah. Konsekuensi logis dari tuntutan profesionalitas ini adalah kemampuan menemukan strategi pembelajaran yang tepat sesuai dengan permasalahan tersebut.

$\begin{array}{ccr}\begin{array}{c}\text { Sebagai } \\ \text { memaksimalkan }\end{array} & \text { upaya } & \text { untuk } \\ \text { proses } & \text { belajar }\end{array}$
mengajar, dalam penelitian ini digunakan model pembelajaran Project Based Learning. Model pembelajaran Project Based Learning ini selain memuat uraian singkat materi Hakikat Ilmu Kimia, utamanya memberikan proyek praktikum pembuatan sabun cuci motor, sebagai suatu produk yang biasa ditemukan dalam kehidupan sehari-hari, namun biasanya hampir setiap orang menanyakan bahan apa yang terkandung dalam produk sabun cuci motor dan bagaimana cara membuatnya. Pertanyaan yang familiar tersebut akan merangsang rasa penasaran siswa sebagai insan akademisi untuk mencoba mencari tahu untuk menjawab pertanyaan tersebut. Hal inilah yang akan menjadi persoalan menarik untuk dipecahkan.

Kelebihan Model pembelajaran Project Based Learning memberikan pengalaman langsung terkait dengan apa 
yang sedang dipelajari (Poppy, 2017). Kombinasi sinergis antara Model pembelajaran Project Based Learning dengan metode praktikum pembuatan produk sabun cuci motor akan menyajikan pembelajaran kontekstual yang menyenangkan, layaknya seorang peneliti sekaligus secara tidak langsung menumbuhkan jiwa kewirausahaan.Dengan menggunakan Model pembelajaran Project Based Learning pada materi Hakikat Ilmu Kimia, berimbas pada keterlibatan keseluruhan materi tersebut dalam pembelajaran dimana turunan materi tersebut meliputi Kedudukan Ilmu Kimia terhadap Ilmu Sains Lainnya, Keselamatan dan Keamanan Kerja di Laboratorium termasuk Pengenalan Peralatan dan Bahan Kimia, Metode Ilmiah dan Peran Kimia dalam Kehidupan.

Model pembelajaran Project Based Learning merupakan pembelajaran berkelompok yang dapat memfasilitasi variasi modalitas cara belajar siswa terutama dalam aspek verbal, kinesik, visual dan auditori yang dalam waktu bersamaan mendorong siswa bekerja sama mengambil peran yang aktif dalam kelompoknya. dengan demikian diharapkan strategi ini dapat meningkatkan hasil belajar siswa (Rusman, 2010). Implementasi PjBL dalam pembelajaran diketahui dapat meningkatkan hasil belajar, keterampilan proses sains serta menjadikan pembelajaran semakin efektif kognitif (Baran \& Maskan, 2010; Cook, Buck, \& Rogers, 2012; Movahedzadeh, Patwell, Rieker, \& Gonzalez, 2012; Özer \& Özkan, 2012).

Penggunaan metode pembelajaran yang tepat sangat berperan dalam kesuksesan siswa meraih hasil belajar yang optimal. Pemilihan model-metode dan penerapannya dalam pembelajaran diperlukan kejelian guru untuk menganalisis kondisi siswa, materi pembelajaran, dan lingkungan serta fasilitas yang ada. Dengan pertimbangan efektivitas waktu dengan hasil yang maksimal, strategi ini merupakan salah satu alternatif dalam meningkatkan hasil belajar pokok bahasan Hakikat Ilmu Kimia, sehingga akan dapat dipahami dan dikuasai oleh siswa dan pada akhirnya mencapai hasil belajar yang maksimal. Dari uraian diatas penulis tertarik untuk melakukan penelitian dengan judul "Peningkatan Hasil Belajar Kimia Menggunakan Model Pembelajaran Project Based Learning pada Pokok Bahasan Hakikat Ilmu Kimia Siswa Kelas X MIPA-1SMA Islam Sultan Agung 2 Jepara Semester 1 Tahun Pelajaran 20182019”. Oleh sebab itu, tujuan dari penelitian ini adalah untuk mengetahui apakah pembelajaran menggunakan model Project Based Learning dapat meningkatkan hasil belajar siswa pada pelajaran kimia dengan pokok bahasan Hakikat Ilmu Kimia, serta untuk mengetahui besar peningkatannya.

\section{METODE}

\section{Jenis Penelitian}

Penelitian ini merupakan Penelitian Tindakan Kelas yang menerapkan model dalam pembelajaran Kimia dalam dua siklus.

\section{Waktu dan Tempat Penelitian}

Waktu pelaksanaan penelitian berlangsung 25 Juli s.d 18 Agustus 2018. Tempat penelitian di SMA Islam Sultan Agung 2 Kalinyamatan Jepara.

\section{Subyek Penelitian}

Penelitian ini melibatkan dua guru kimia sebagai observer. Adapun subyek penelitian adalah 33 siswa kelas X MIPA-1 yang keadaan siswa tersebut heterogen. 


\section{Prosedur Penelitian}

Bagan alir siklus penelitian tindakan kelas ini disajikan dalam Gambar 1.

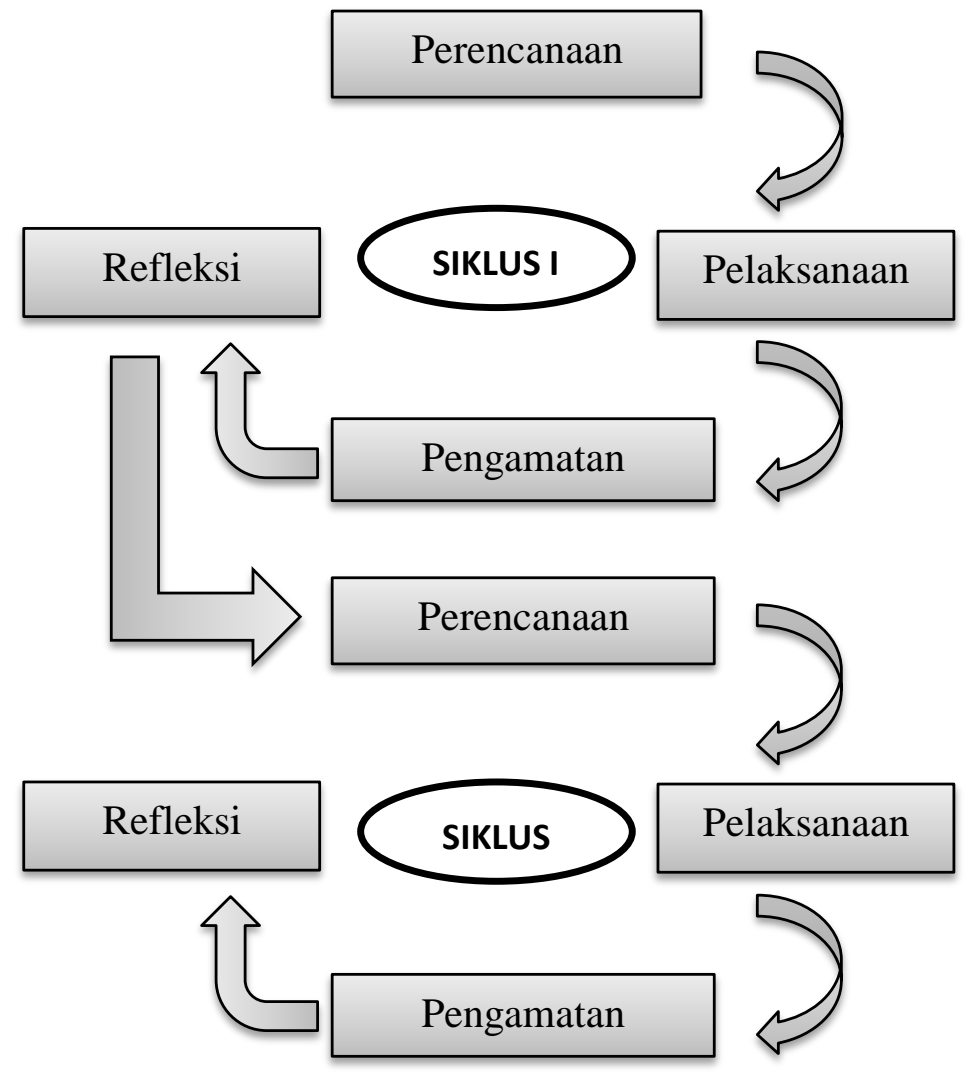

Gambar 1. Bagan Alir Penelitian Tindakan Kelas

\section{Prosedur Siklus I}

\section{Perencanaan Penelitian}

Kegiatan perencanaan terdiri dari: 1) Menentukan materi pembelajaran; 2) Menyusun silabus, RPP dan desain pembelajaran, 3) Membuat instrumen untuk mengukur hasil belajar Hakikat Ilmu Kimia, 4) Mendesain instrumen observasi aktifitas guru sebagai fasilitator dan observasi pelaksanaan sintak PjBL, 5) Mendesain instrumen observasi keaktifan siswa dalam menerapkan model pembelajaran $\mathrm{PjBL}, 6$ ) Menyusun Lembar Kerja (LK)-1 Diskusi Siswa, 7) Menyusun LK-2 Diskusi Siswa, 8) Menyusun LK-3 Rancangan Proyek lengkap dengan jadwalnya, 9) Menyusun angket ketertarikan siswa, 10) Membuat daftar hadir, 11) Membagi siswa dalam 6 kelompok dan 12) Mempersiapkan perangkat dan bahan yang diperlukan untuk melaksanakan tindakan.

Tindakan

\section{Mengajar}

Kegiatan pada langkah ini terdiri dari: 1) Guru Membagi siswa dalam 6 kelompok, 2) Guru menjelaskan tujuan pembelajaran, 3) Guru menjelaskan cakupan materi pembelajaran, 4) Guru membagikan LK-1 Diskusi dan LK-2 Diskusi, 5) Guru membagikan LK Rancangan Proyek dilengkapi dengan jadwal aktivitas penyelesaian Proyek Pembuatan Sabun Cuci Motor, 6) Guru membagikan lembar angket ketertarikan siswa.

\section{Belajar Kelompok}

Kegiatan belajar kelompok terdiri dari: 1) Ketua kelompok mengkoordinir anggota kelompok untuk melaksanakan kegiatan pembelajaran, 2) Siswa dalam kelompoknya 
mempersiapkan berbagai referensi guna menunjang diskusi kelompok, 3) Siswa dalam kelompoknya diskusi menyusun rancangan proyek dengan merancang pembagian tugas, dan menyusun time schedule, 4) Siswa dalam kelompoknya mengerjakan LK-1 diskusi materi hakikat ilmu kimia dan metode ilmiah, 5) Siswa dalam kelompoknya mengerjakan LK-2 diskusi materi keamanan dan keselamatan laboratorium dan peran kimia, 6) Sebagian siswa menyampaikan pertanyaan kepada guru dan guru menjawab, 7) Semua siswa aktif melaksanakan pencatatan hasil diskusi, 8) Observer melakukan observasi dengan memakai lembar observasi yang telah dipersiapkan, 9) Pada akhir pembelajaran, guru meminta masing-masing kelompok untuk menyampaikan hasil diskusi kelompoknya sesuai dengan topik yang diberikan peneliti, 10) Guru membantu untuk mengarahkan jawaban siswa jika masih ada yang kurang tepat, 11) Guru bersama siswa membuat kesimpulan pada akhir pembelajaran, 12) Tiap kelompok diskusi menyerahkan kepada guru hasil Lembar Kerja sebagai bentuk portofolio kelompok, 13) Siswa melaksanakan postes 1 .

\section{Pengamatan}

Tahap ini dilaksanakan pada waktu tindakan sedang berlangsung. Lembar observasi tersebut meliputi: 1) Lembar observasi Guru, 2) Lembar observasi keaktifan siswa.

\section{Refleksi}

Hasil analisis yang diperoleh dan kendalakendala yang ditemui selama pelaksanaan tindakan, digunakan sebagai bahan refleksi. Hasil refleksi kegiatan digunakan untuk mengetahui perubahan yang terjadi selama penerapan model pembelajaran, hal-hal apa yang perlu diperbaiki dan untuk menentukan apa yang akan dilaksanakan pada siklus II.

\section{Pelaksanaan Siklus II}

\section{Perencanaan Penelitian}

Kegiatan pada tahap ini meliputi: 1) Memperbaiki permasalahan dari hasil identifikasi berdasarkan refleksi pada siklus I; 2) menyusun perbaikan silabus, RPP dan desain pembelajaran; 3) Mempersiapkan lembar observasi meliputi: model pembelajaran, guru, dan keaktifan siswa; 4) Menyusun lembar penilaian psikomotorik siswa meliputi: i) Lembar observasi unjuk kerja meliputi persiapan, pelaksanaan dan penutup, ii) Portofolio meliputi LK-4 Data Pengamatan Praktik pembuatan Sabun Cuci Motor dan LK-5 Draft Laporan Pelaksanaan Praktik Pembuatan Sabun Cuci Motor; 5) Menyusun angket ketertarikan siswa; 6) Membuat daftar hadir; 7) Membagi siswa dalam 6 kelompok, 8) Mempersiapkan perangkat dan bahan yang diperlukan untuk melaksanakan tindakan.

\section{Tindakan}

\section{Mengajar}

Kegiatan pada tahap ini meliputi: 1) Guru mengawali proses pembelajaran dengan memotivasi dan checking bahan, peralatan dan perlengkapan praktik pembuatan sabun cuci motor; 2) Guru menjelaskan tujuan pembelajaran; 3) Guru menjelaskan cakupan materi pembelajaran; 4) Guru menyampaikan aspek penilaian psikomotorik praktik pembuatan sabun cuci motor, 5) Guru membagikan LK Data Pengamatan Praktik Pembuatan Sabun Cuci Motor proses praktikum berlangsung, 6) Guru membagikan Draft Laporan Pelaksanaan Praktik Pembuatan Sabun Cuci Motor, 7) Guru membagikan soal postes 2, 8) Guru membagikan angket ketertarikan siswa siklus 2, 9) Observer melakukan 
observasi dengan memakai lembar observasi yang telah dipersiapkan.

\section{Belajar Kelompok}

Kegiatan pada tahap belajar kelompok ini meliputi: 1) Siswa bersama kelompoknya melaksanakan kegiatan persiapan unjuk kerja praktikum pembuatan sabun cuci motor; 2) Ketua kelompok mengkoordinir anggota kelompok untuk melaksanakan kegiatan praktikum pembuatan sabun cuci motor; 3) Siswa dalam kelompoknya melaksanakan ceking persiapan kelengkapan dalam melaksanakan unjuk kerja praktikum pembuatan sabun cuci motor; 4) Siswa dalam kelompoknya melaksanakan praktikum sesuai dengan perannya; 5) Siswa yang berperan sebagai notulen menulis berbagai data pengamatan yang diperoleh selama praktikum berlangsung; 6) Siswa membersihkankan berbagai perlengkapan dan peralatan praktikum setelah praktikum selesai, 7) Siswa dalam kelompoknya merancang penyusunan laporan praktikum disesuaikan dengan draft laporan dari guru, 8) Sebagian siswa menyampaikan pertanyaan kepada guru dan guru menjawab, 9) Siswa dalam kelompoknya melakukan penyusunan laporan praktikum disesuaikan dengan draft laporan dari guru, 10) Beberapa kelompok diberi kesempatan untuk memaparkan hasil praktikum sesuai dengan laporan yang telah disusun; 11)Pada akhir pembelajaran, guru meminta masing-masing kelompok untuk menyampaikan pendapat sebagai persamaan persepsi dengan kelompok lainnya; 12) Guru membantu untuk mengarahkan jawaban siswa jika masih ada yang kurang tepat; 13) Guru bersama siswa membuat kesimpulan pada akhir pembelajaran; 14) Tiap kelompok mengumpulkan laporan praktikum yang telah disusun; 15) Siswa melaksanakan postes siklus 2; dan 16) Siswa menjawab angket ketertarikan siswa siklus 2.

\section{Pengamatan}

Tahap ini dilaksanakan pada waktu tindakan sedang berlangsung. Lembar observasi tersebut meliputi: 1) Lembar observasi Guru; 2) Lembar observasi keaktifan siswa; 3) Lembar observasi unjuk kerja.

\section{Refleksi}

Hasil analisis selama pelaksanaan tindakan, digunakan sebagai bahan refleksi. Hasil refleksi kegiatan digunakan untuk mengetahui perubahan yang terjadi selama penerapan model pembelajaran, dan berguna untuk mengambil keputusan apakah siklus akan diakhiri sesuai dengan perencanaan.

\section{Kriteria Keberhasilan Penelitian}

Indikator keberhasilan penelitian tindakan kelas ini adalah dengan semakin meningkatnya hasil belajar siswa dengan ditandai ketertarikan, keaktifan dan hasil belajar siswa meningkat yaitu sekurangkurangnya $80 \%$ dari jumlah siswa memperoleh nilai rata-rata tuntas belajar secara individual mencapai $75 \%$.

\section{HASIL DAN PEMBAHASAN}

Data Penilaian Kognitif peningkatan hasil belajar diperoleh dari hasil test pretes pada prasiklus hanya 18 siswa yang mencapai KKM dengan persentase sebesar $55 \%$, sedangkan 15 siswa belum mencapai KKM. Kemudian terjadi peningkatan nilai postes I dimana 25 siswa mencapai KKM dengan persentase $76 \%$ sedangkan 8 siswa belum mencapai KKM sehingga belum memenuhi target dan dilanjutkan pada siklus II terjadi peningkatan dimana 32 siswa mencapai KKM dengan persentase 97\% sedangkan 1 siswa belum mencapai KKM. Nilai kognitif siswa hasil pretes dan postes disajikan dalam Tabel 1. 
Tabel 1. Data Penilaian Kognitif

\begin{tabular}{|c|c|c|c|}
\hline Nilai Kognitif & Pretes & $\begin{array}{c}\text { Postes } \\
\text { I }\end{array}$ & $\begin{array}{c}\text { Postes } \\
\text { II }\end{array}$ \\
\hline Nilai Rata-rata & 65 & 78 & 90 \\
\hline $\begin{array}{l}\text { Jumlah siswa } \\
\text { belum } \\
\text { mencapai } \\
\text { KKM }\end{array}$ & 15 & 8 & 1 \\
\hline $\begin{array}{l}\text { Jumlah siswa } \\
\text { yang mencapai } \\
\text { KKM }\end{array}$ & 18 & 25 & 32 \\
\hline $\begin{array}{l}\text { Prosentase } \\
\text { Capaian KKM }\end{array}$ & $55 \%$ & $76 \%$ & $97 \%$ \\
\hline
\end{tabular}

Berdasarkan Tabel 1, dapat dilihat bahwa terdapat peningkatan nilai kognitif dari pretes ke postes I. Pada siklus I siswa dilibatkan dalam diskusi mengenai metode ilmiah dan keselamatan laboratorium. Siswa juga diminta untuk membuat sebuah rancangan mengenai proyek pembuatan sabun cuci motor pada siklus I. Beberapa solusi diberikan oleh siswa mengenai cara yang tepat untuk membuat sabun cuci motor. Kegiatan inilah yang meningkatkan nilai dan persentase capaian KKM siswa dari55\% pada pretes menjadi $76 \%$ pada postes I.

Hasil pada postes II terjadi peningkatan yang cukup signifikan dibanding pretes dan postes I. Siklus II merupakan refleksi dan perbaikan dari siklus I. Pada siklus I, siswa belum dilibatkan secara langsung dalam kegiatan praktikum dan baru pada tahap perancangan sedangkan pada siklus II siswa sudah melakukan praktikum pembuatan sabun cuci motor. Rancangan pembuatan sabun cuci motor pada siklus I diterapkan pada siklus II, dengan bahan dan langkah kerja yang dibuat secara mandiri oleh siswa.

Hal ini telah sesuai dengan beberapa penelitian sebelumnya yang mengungkapkan bahwa model pembelajaran Project Based Learning dapat meningkatkan hasil belajar siswa pada aspek kognitif, afektif maupun psikomotorik (Addiin, Redjeki, \& Dwi, 2014; Yance, Ramli, \& Mufit, 2013). Siswa diwajibkan aktif untuk mengkonstruksi kerangka konseptual mereka secara mandiri melalui sintaks dalam Project Based Learning. Pada kegaitan perancangan proyek pembuatan sabun cuci motor siswa diharuskan memahami berbagai konsep dasar kimia yaitu unsur, senyawa dan campuran, asam, basa dan garam. Konsep-konsep tersebut sangat penting untuk memastikan bahwa bahan-bahan yang akan mereka gunakan dalam proyek sudah tepat dan berhasil membuat sabun cuci motor.

\section{Data Penilaian Psikomotorik}

Data Penilaian psikomotorik diperoleh dari portofolio dan unjuk kerja/praktik dengan perbandingan proporsi nilai 60\%:40\%. Nilai portofolio meliputi LK-1 Diskusi, LK-2 Diskusi, LK-3 Perencanaan Proyek, LK-4 Pelaksanaan Proyek, dan Laporan Proyek dengan proporsi nilai maksimal berurutan 15:15:20:20:30. Sedangkan nilai unjuk kerja/praktik berdasarkan lembar pengamatan meliputi persiapan, pelaksanaan, dan penutup dengan proporsi nilai maksimal berurutan 30:40:30. Bagan nilai psikomotorik siswa antar kelompok disajikan pada Gambar 2. 
Nilai Psikomotorik Antar Kelompok

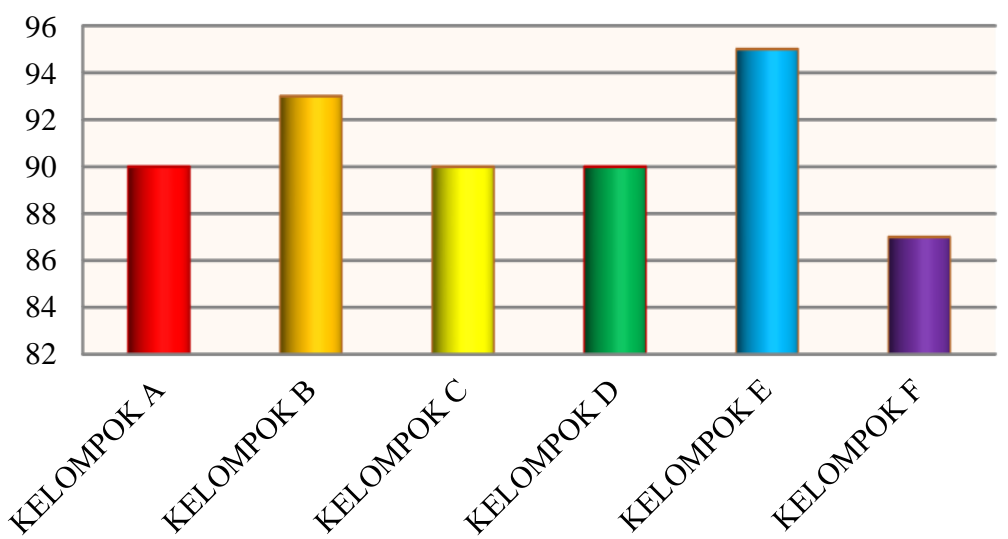

Gambar 2. Bagan Nilai Psikomotorik Kelompok

Secara keseluruhan siswa semakin aktif dalam proses pembelajaran, terjadi selama siklus II berlangsung. Model pembelajaran Project Based Learning lengkap dengan sintaknya mempermudah dan memperjelas langkah yang akan dilakukan, karena semua langkah prosedural pembelajaran menyajikan tahapan praktis proses pembelajaran yang akan dilaksanakan. Dengan demikian langkah ini akan menuntun siswa step by step sehingga siswa menjadi aktif dan saling bekerjasama. Penilaian psikomotorik berupa nilai portofolio dan unjuk kerja menjadikan siswa semakin aktif dan bekerja sama dalam masing-masing kelompoknya selama proses pembelajaran. Hasil rekap nilai psikomotorik menunjukkan bahwa semua siswa telah mencapai KKM. Urutan Perolehan nilai psikomotorik dari besar menuju kecil, nilai tertinggi diperoleh oleh kelompok E, kelompok B, kelompok C, kelompok A, kelompok D dan kelompok F. Rekapitulasi data penilaian psikomotorik siswa disajikan dalam Tabel 2.

Tabel 2. Data Penilaian Psikomotorik

\begin{tabular}{|c|c|c|c|c|c|c|c|c|}
\hline \multirow[b]{3}{*}{ Kriteria } & \multicolumn{8}{|c|}{ Nilai Psikomotorik } \\
\hline & \multicolumn{5}{|c|}{ Portofolio } & \multicolumn{3}{|c|}{ Unjuk Kerja } \\
\hline & $\begin{array}{c}\text { LK-1 } \\
\text { Diskusi }\end{array}$ & $\begin{array}{c}\text { LK-2 } \\
\text { Diskusi }\end{array}$ & $\begin{array}{c}\text { LK-3 } \\
\text { Perencanaan } \\
\text { Proyek }\end{array}$ & $\begin{array}{c}\text { LK-4 } \\
\text { Pelaksanaan } \\
\text { Proyek }\end{array}$ & $\begin{array}{c}\text { Laporan } \\
\text { Proyek }\end{array}$ & Persiapan & Pelaksanaan & Penutup \\
\hline Rata-rata & 94,95 & 100 & 91,67 & 91,67 & 83,33 & 97,98 & 87,5 & 100 \\
\hline $\begin{array}{c}\text { Jumlah } \\
\text { Siswa }\end{array}$ & 33 & 33 & 33 & 33 & 33 & 33 & 33 & 33 \\
\hline $\begin{array}{l}\text { Mencapai } \\
\text { KKM }\end{array}$ & & & & & & & & \\
\hline $\begin{array}{c}\text { Prosentase } \\
\text { Siswa } \\
\text { yang }\end{array}$ & $100 \%$ & $100 \%$ & $100 \%$ & $100 \%$ & $100 \%$ & $100 \%$ & $100 \%$ & $100 \%$ \\
\hline $\begin{array}{c}\text { Mencapai } \\
\text { KKM }\end{array}$ & & & & & & & & \\
\hline
\end{tabular}


Berdasarkan Tabel 2, diketahui bahwa nilai psikomotorik siswa pada semua komponen penilaian baik pada penilaian portofolio maupun unjuk kerja sudah mencapai KKM. Pada komponen LKdiskusi dan penutup praktek mendapat nilai ketuntasan maksimal yaitu 100\%. Nilai psikomotorik siswa kurang bervariasi karena mereka memiliki hasil belajar yang hampir sama. Beberapa siswa kurang aktif dalam melakukan diskusi saat mengerjakan LK- 1, pada materi materi hakikat ilmu kimia dan metode ilmiah, sehingga nilai portofolio individu mereka kurang bagus dibandingkan yang lain. Materi ini adalah materi dasar yang harus dikuasai siswa sebelum bisa merancang sebuah proyek mengenai pembuatan sabun cuci motor. Partisipasi dan pemahaman konsep siswa dalam kegiatan diskusi menentukan nilai psikomotorik mereka.

Praktikum sebagai hasil dari rancangan proyek siswa melibatkan siswa secara langsung dalam kegiatan pembelajaran. sesuai Teori Kerucut Pengalaman Dale, keterlibatan siswa dalam sebuah kegiatan pembelajaran akan meningkatkan hasil belajar mereka khususnya ranah psikomotorik yang lebih berkenaan dengan kinerja dan aktifitas fisik. Penelitian yang dilakukan oleh Fajarwati, Susilo, \& Indriwati (2017) menunjukkan bahwa pembelajaran berbasis Project Based Learningdapat meningkatkan hasil belajar siswa pada ranah psikomotorik dan keterampilan memecahkan masalah.

\section{Data Penilaian Afektif}

Nilai afektif digunakan untuk mengetahui gambaran ketertarikan dan keaktifan siswa dalam melaksanakan pembelajaran berbasis proyek. Nilai afektif diperoleh dari dua sumber yaitu, angket ketertarikan siswa dan pengamatan keaktifan siswa secara kelompok. Ada 10 butir soal angket ketertarikan siswa meliputi ketertarikan terhadap pelajaran kimia pokok materi Hakikat Kimia menggunakan model pembelajaran Project Based Learning. Hasil angket ketertarikan siswa pada siklus I dan siklus II disajikan dalam Gambar 3.

\section{Rerata Skor Angket Ketertarikan Siswa}

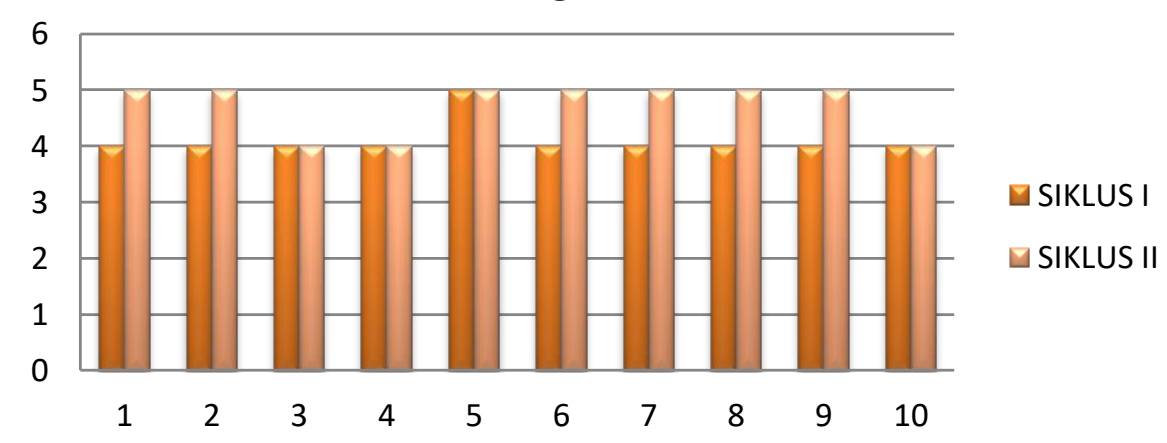

Gambar 3. Rerata Skor Angket Ketertarikan Siswa Tiap Siklus

Berdasarkan Gambar 3, terdapat kenaikan rerata skor ketertarikan siswa terhadap pembelajaran pada materi Hakikat Kimia menggunakan model pembelajaran Project
Based Learning. Pembelajaran menggunakan model pembelajaran Project Based Learning menunjukkan bahwa siswa semakin tertarik dan berantusias. Angket 
Ketertarikan Siswa siklus I rata-rata 84 dan meningkat pada siklus II rata-rata 92. Namun khusus untuk butir 3, 4 dan 10 tidak mengalami peningkatan skor pada siklus II dan tetap berada pada interval nilai 4 yaitu 1) pembelajaran yang membimbing siswa merancang tujuan secara mandiri dalam memecahkan masalah; 2) pembelajaran yang membimbing anda menyusun rancangan dalam memecahkan masalah; dan 3) apakah anda merasa senang dan tertarik terhadap pembelajaran menyusun laporan dan memberi kesempatan merepresentasinkannya.

Dari ketiga point diatas menunjukkan bahwa siswa belum siap untuk merancang tujuan secara mandiri, menyusun rancangan pemecahan masalah, dan menulis laporan. Ketiga ketrampilan berfikir tersebut tidak dapat serta merta dimiliki oleh siswa namun diperoleh melalui proses panjang pembelajaran, guru dapat membantu membimbing dan mengarahkan agar siswa dapat mencapai ketrampilan tersebut yaitu salah satunya dengan cara memberikan format instrumen yang mengarahkan dan membimbing siswa agar siswa terstimulus dalam merancang tujuan secara mandiri, menemukan ide dalam memecahkan masalah dan dapat menyusun laporan berdasarkan fakta lapangan dan menginterpretasikannya.

\section{Prosentase Keaktifan Kelompok}

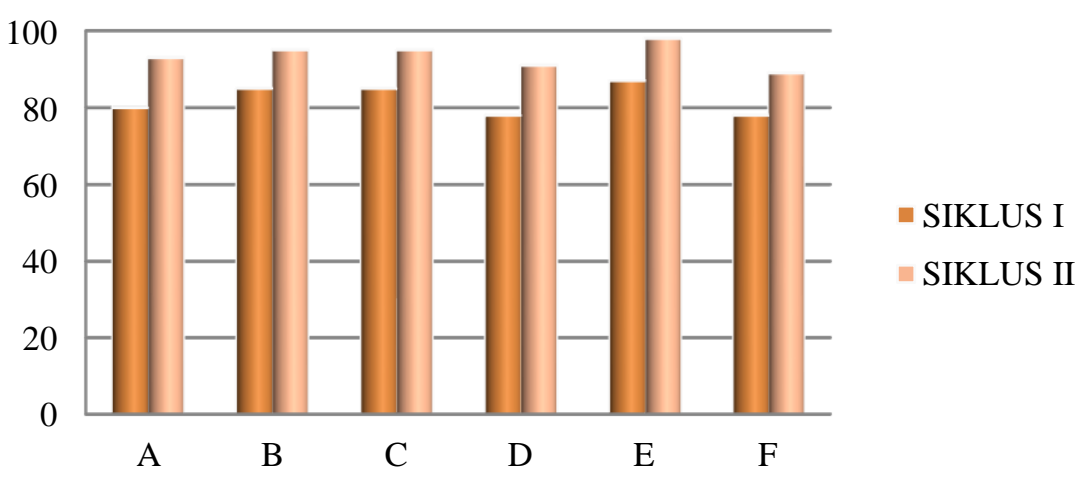

Gambar 4. Keaktifan Kelompok Siklus I dan Siklus II

Nilai keaktifan siswa meningkat berdasarkan pengamatan pada siklus I ratarata 82, sedangkan pada siklus II rata-rata 93. Demikian pula observasi pada kecakapan guru dalam mengajar terjadi peningkatan pada siklus I rata-rata 88 , sedangkan pada siklus II rata-rata 97. Dengan melihat berbagai data menunjukkan bahwa pembelajaran menggunakan model pembelajan Project Based Learning terbukti dapat menggugah rasa antusiasme siswa, meningkatkan rasa ingin tahu, meningkatkan ketertarikan siswa terhadap pembelajaran kimia, meningkatkan keaktifan siswa yang pada akhirnya dapat meningkatkan hasil belajar siswa. Model Project Based Learning mampu menumbuhkan ketertarikan siswa terhadap pembelajaran (Yalçin, Turgut, \& Büyükkasap, 2009). Hasil penelitian ini sesuai dengan penelitian-penelitian sebelumnya bahwa model pembelajaran Project Based Learning dapat meningkatkan hasil belajar siswa (Jagantara, Adnyana, Widiyanti, \& Si, 2014; Pradita, Mulyani, \& Redjeki, 2015; Susanti \& Muchtar, 2008; Yance et al., 2013). 


\section{SIMPULAN DAN SARAN}

\section{Simpulan}

Berdasarkan uraian hasil penelitian dan pembahasan pada bab sebelumnya, akhirnya dapat peneliti simpulkan sebagai berikut: 1. Pembelajaran model Project Based Learning dapat meningkatkan hasil belajar siswa pada pelajaran kimia dengan pokok bahasan Hakikat Ilmu Kimia. Model Project Based Learning sangat relevan dengan Ilmu Kimia karena kimia tidak hanya membahas tentang zat-zat secara teoretis, tetapi juga membahas secara empiris dan bernilai kontekstual. Ilmu kimia merupakan ilmu yang diperoleh melalui kerja ilmiah, sehingga dalam mempelajari ilmu kimia ada dua hal yang harus dipelajari, yaitu aspek produk (fakta, konsep, prinsip, teori, hukum) dan aspek empiris; 2. Guru telah berhasil menerapkan model pembelajaran Project Based Learningpokok bahasan Hakikat Ilmu Kimia. Terjadi peningkatan nilai kognitif dari $55 \%$ menjadi $97 \%$ ketuntasan belajar. Nilai psikomotorik bersumber dari nilai portofolio dan unjuk kerja pembuatan sabun cuci motor menunjukkan capaian yang memuaskan dengan rata-rata nilai 91 dan $100 \%$ tuntas belajar. Kegiatan pembelajran project ini mengakibatkan ketertarikan siswa meningkat dari siklus I rata-rata 84 menjadi rata-tata 92 pada siklus II. Keaktifan siswa juga meningkat pada $82 \%$ siklus I menjadi 93\% pada siklus II. Kecakapan guru juga semakin mantap dari $88 \%$ siklus I menjadi 97\% siklus II. Secara keseluruhan keberhasilan penerapan PjBL sebesar 95\%. Dengan demikian menunjukkan bahwa penerapan model pembelajaran PjBL meningkatkan hasil belajar siswa. Guru berhasil membuat siswa memahami materi dengan baik manakala hasil belajar siswa meningkat (Rumbekwan, Yohanita, \& Damopolii, 2018).

\section{Saran}

Sehubungan dengan kesimpulan yang telah diambil, maka saran yang dapat penulis sampaikan adalah sebelum diadakannya pembelajaran, perlu diadakan sosisalisasi kepada siswa terkait dengan tata cara dan aturan model pembelajaran PjBL, supaya pembelajaran dapat berjalan lancar. Juga perlu disadari, bahwa keberhasilan proyek juga dikarenakan kejelasan dalam memberikan informasi baik dari sisi konten maupun prosedur terkait dengan tugas proyek tersebut.

\section{DAFTAR PUSTAKA}

Addiin, I., Redjeki, T., \& Dwi, R. (2014). Penearapan model pembelajaran Project Based Learning (PjBL) pada materi pokok larutan asam dan basa di kelas XI IPA I SMA Negeri 2 Karanganyar, 3(4), 7-16.

Baran, M., \& Maskan, A. (2010). The Effect of Projectbased learning on pre-service physics teachers' electrostatic achievements. Cypriot Journal of Educational Sciences, 5, 243-257.

Cook, K., Buck, G., \& Rogers, M. P. (2012). Preparing Biology teachers to teach evolution in a Project-Based Approach. Winter, 21(2), 18-30.

Fajarwati, S. K., Susilo, H., \& Indriwati, S. E. (2017). Pengaruh Project Based Learning berbantuan multimedia terhadap keterampialn memecahkan masalah dan hasil belajar psikomotor siswa kelas XI SMA, 2(3), 315-321.

Jagantara, I. M. W., Adnyana, P. B., Widiyanti, N. L. P. M., \& Si, S. (2014). Pengaruh model pembelajaran berbasis proyek (Project Based Learning) terhadap hasil belajar biologi ditinjau 
dari gaya belajar siswa SMA. Jurnal Pendidikan Dan Pembelajaran IPA Indonesia, 4(1), 1-13.

Komalasari, K. (2009). The Effect of contextual learning in Civic Education on students' civic competence. Journal of Social Sciences, 5(4), 261-270.

Movahedzadeh, F., Patwell, R., Rieker, J. E., \& Gonzalez, T. (2012). Projectbased learning to promote effective learning in biotechnology courses. Education Research International, 2012, 1-8.

Özer, D. Z., \& Özkan, M. (2012). The Effect of the project based learning on the science process skills of the prospective teachers of science. Journal of Turkish Science Education, 9(3), 131-136.

Poppy, K. D. (2017). Model-model pembelajaran IPA dan implementasinya. Bandung: PPPPTK IPA.

Pradita, Y., Mulyani, B., \& Redjeki, T. (2015). Penerapan model pembelajaran Project Based Learning untuk meningkatkan prestasi belajar dan kreativitas siswa pada materi pokok sistem koloid kelas XI IPA semester genap Madrasah Aliyah Negeri Klaten
Tahun Pelajaran 2013/2014. Jurnal Pendidikan Kimia, 4(1), 89-96.

Rumbekwan, Y. O., Yohanita, A. M., \& Damopolii, I. (2018). Pengaruh model pembelajaran Cooperative Script terhadap hasil belajar Biologi di kelas VIII SMP 11 Manokwari. JIPVA (Jurnal Pendidikan IPA Veteran), 2(1), 25-35.

Rusman, R. (2010). Model-model pembelajaran. Jakarta: Rajawali Pers.

Susanti, E., \& Muchtar, Z. (2008). Pendekatan project based learning untuk pembelajaran kimia koloid di SMA. Jurnal Pendidikan Matematika \& Sains, 3(2), 106-112.

Yalçin, S. A., Turgut, U., \& Büyükkasap, E. (2009). The Effect of PjBL on science undergraduates' learning of electricity, attitude towards physics and scientific process skills. International Online Journal of Educational Sciences (IOJES), 1(1), 81-105.

Yance, R. D., Ramli, E., \& Mufit, F. (2013). Pengaruh model Project Based Learning (PjBL) terhadap hasil belajar siswa kelas XI IPA SMA Negeri 1 Batiputuh Kabupaten Tanah Datar, 1(April), 48-54. 